\title{
UNILATERAL OVARIECTOMY DURING PREGNANCY IN MICE
}

\author{
MARY H. ROSS* AND HEATHER M. BEAUMONT \\ Department of Anatomy, Medical School, University of Birmingham, \\ Birmingham B15 2 TJ
}

(Received 10th May 1974)

Ovarian hormones are essential for the maintenance of pregnancy in the mouse, bilateral ovariectomy at any stage of gestation resulting in death of the conceptuses (Harris, 1927). Studies of the effect of removing a proportion of the ovarian tissue have generally been confined to those in which one ovary was excised during the period between ovulation and implantation, when survival of the zygote and its passage from oviduct to uterus was probably affected by the procedure (Bruce, Renwick \& Finn, 1968; Wu \& Dickmann, 1971). The present experiment was undertaken to investigate the effect of unilateral ovariectomy, carried out after implantation, on the development and survival of conceptuses: it was designed to test the hypothesis that a quantitative relationship exists between ovarian tissues and the number of young carried to term. On this basis we predicted that hemiovariectomy would be followed either by the death of a proportion of the conceptuses, or by compensatory changes in the ovary which remained in situ.

Thirty-four virgin female mice of the C57BL (black) strain, aged 4 to 5 months, were housed with males and the day on which mating occurred was designated Day 0.5 of pregnancy.

Unilateral ovariectomy or a sham-operation was carried out on Day 8.5 , 11.5 or 14.5 . Surgery was performed on alternate sides in successive animals. This procedure was adopted in an attempt to avoid bias since the right ovary is reported to ovulate more oocytes than the left (McLaren, 1963a) and hence would be expected to contain more hormone-secreting tissue in the form of large follicles and CL. Anaesthesia was induced by means of tribromoethyl alcohol (Avertin). The ovary was removed through a small incision in the lumbar region; the oviduct and associated blood vessels were ligated with surgical silk. In control animals, one ovary was exposed, manipulated and returned to the abdominal cavity.

All animals were killed at 18.5 days by a lethal dose of anaesthetic. The gonads which remained in situ were removed and placed in Bouin's aqueous fixative. The number of implantation sites was recorded and the contents of each uterine horn were dissected and classified according to the following criteria: (i) normal: body form and size characteristic for 18.5 days (crown-

* Present address: Mrs Mary H. Metcalfe (née Ross), University of Rhodesia, Medical School, Salisbury, Rhodesia. 
rump length, 18 to $23 \mathrm{~mm}$ : Theiler, 1972); viable, i.e. showed a reflex response to mechanical stimulation; (ii) retarded or abnormal: the fetus had not attained the degree of development expected, or had physical abnormalities and/or was non-viable; (iii) mid-pregnancy death: embryo tissues autolysed; placental remains identifiable; (iv) early death or 'mole': small atrophic conceptus (resorption site).

Serial sections (10 $\mu \mathrm{m}$ thick) of each ovary were made, using conventional histological techniques. The sections were scanned in sequence $\times 80$ and the number of Graafian follicles and luteal bodies was recorded. The volume of tissue in each luteal body was estimated, using the formula which gives the volume of an elliptical body, $4 / 3 r_{1}, r_{2}, r_{3}$, where $r_{1}$ and $r_{2}$ are radii at right angles, measured by a micrometer eyepiece in the section judged to contain the maximal cross-sectional area of each luteal body, and $\mathrm{r}_{3}$ represents half the depth of the luteal body (estimated from a count of the number of sections in which it occurred). Two diameters of each Graafian follicle were measured in the section which contained the nucleolus of the oocyte. Each luteal body was also examined at a higher magnification $(\times 320)$ and those judged from their cellular morphology to contain functional luteal tissue were classified as follows (Ross, 1973): (i) true CL of pregnancy; (ii) atretic CL, containing a 'trapped' oocyte; (iii) 'nodules' of luteal cells, smaller in diameter than a Graafian follicle.

Standard statistical procedures were used (see below). Analyses of variance were carried out on data derived from control animals in order to examine their homogeneity. When the results showed that differences between groups were not significant, the data for all control animals were pooled for comparison with experimental groups.

The mean number of implantation sites in control and experimental animals (grouped) was 7.13 (S.D. = 1.67). Postimplantation loss, i.e. the total number of implantation sites minus the number of viable fetuses, was calculated for each mouse. Table 1 shows that the mean postimplantation loss was similar in all groups, though possibly greater when ovariectomy was performed at 11.5 days. There were two animals in this group in which all the conceptuses (litters of seven and eight) were degenerating. The results of an analysis of variance, carried out after suitable transformation of the data, indicated that differences between the six groups were, overall, far from significant and hence the exceptional losses in the 11.5-day group could possibly be ascribed to sampling peculiarities, although the possibility that the failure of pregnancy was a consequence of hemiovariectomy cannot be discounted. Assessment of the degenerating implantation sites (Table 1) indicated that death occurred at mid-pregnancy after the placenta had been vascularized by allantoic mesoderm (c. 10.0 days: Theiler, 1972; Pritchard \& Huggett, 1947).

Almost all the fetuses in hemiovariectomized animals were normal and viable (Table 1). The total fetal weight and total placental weight per mother was calculated: analysis of variance showed no evidence of difference between the control and hemiovariectomized mice in either parameter. The data were therefore pooled: mean values for total fetal weight and total placental weight per mother were $6.22 \mathrm{~g}$ (S.D. $=1.72)$ and $0.530 \mathrm{~g}$ (S.D. $=0.156)$, respectively. 
Table 1. Numbers of degenerating and retarded or abnormal conceptuses found at 18.5 days in mice hemiovariectomized or subjected to sham-operation

\begin{tabular}{|c|c|c|c|}
\hline & \multicolumn{3}{|c|}{ Stage of pregnancy at operation (days) } \\
\hline & 8.5 & $11 \cdot 5$ & 14.5 \\
\hline $\begin{array}{l}\text { Controls } \\
\text { Mean }\end{array}$ & $\begin{array}{ll}0 & - \\
1 & (\mathrm{R}) \\
2 & (\mathrm{R}) \\
- & - \\
1.00\end{array}$ & $\begin{array}{ll}1 & (\mathrm{M}) \\
1 & (\mathrm{M}) \\
4 & (2 \mathrm{M}, 2 \mathrm{MP}) \\
0 & - \\
1 \cdot 50\end{array}$ & $\begin{array}{ll}1 & (\mathrm{M}) \\
0 & - \\
4 & (\mathrm{M}) \\
- & - \\
1.66\end{array}$ \\
\hline Hemiovariectomized & $\begin{array}{ll}1 & (\mathbf{M}) \\
1 & (\mathbf{M}) \\
2 & (\mathbf{M}) \\
2 & (\mathbf{M}) \\
4 & (\mathbf{M}) \\
1 & (\mathbf{M}) \\
0 & -\end{array}$ & $\begin{array}{ll}7 & (\mathrm{MP}) \\
3 & (\mathrm{M}) \\
1 & (\mathrm{M}) \\
1 & (\mathrm{M}) \\
1 & (\mathrm{R}) \\
2 & (\mathrm{M}) \\
8 & (1 \mathrm{M}, 7 \mathrm{MP})\end{array}$ & $\begin{array}{ll}1 & (\mathrm{M}) \\
1 & (\mathrm{M}) \\
1 & (\mathrm{R}) \\
2 & (\mathrm{M}) \\
1 & (\mathrm{R}) \\
1 & (\mathrm{R}) \\
- & -\end{array}$ \\
\hline Mean & 1.57 & $3 \cdot 28$ & $1 \cdot 16$ \\
\hline
\end{tabular}

$\mathbf{M}=$ 'mole' or early death; $\mathrm{MP}=$ mid-pregnancy death; $\mathbf{R}=$ retarded or abnormal fetus.

These observations provide a further indication that development proceeded normally, even though one ovary had been removed.

On the other hand, four mice which were hemiovariectomized (one at 8.5 days, one at 11.5 days and two at 14.5 days) reached or completed parturition by the time of autopsy, 2 days before the expected date. None of the control mice gave birth.

The mean numbers of Graafian follicles found in experimental and control mice are shown in Table 2. Both non-parametric rank tests and analyses of variance failed to show significant differences between the three experimental groups, or between control and experimental mice. These findings demonstrate that compensation occurs in the ovary which remains after hemiovariectomy with respect to the number of Graafian follicles: there was no change in follicular size.

Preliminary analyses of variance on data derived from the histological study of CL in control mice showed no evidence of difference (a) between ovaries

Table 2. The number of Graafian follicles in the single ovary of hemiovariectomized mice and the two ovaries of controls subjected to shamoperation

\begin{tabular}{|c|c|c|c|c|}
\hline & \multirow{2}{*}{ Controls } & \multicolumn{3}{|c|}{ Hemiovariectomized animals } \\
\hline & & 8.5 days* & $11 \cdot 5$ days & 14.5 days \\
\hline No. of animals & 10 & 6 & 6 & 6 \\
\hline Mean (range) & $\begin{array}{c}13 \cdot 10 \\
(7 \text { to } 16)\end{array}$ & $\begin{array}{c}11 \cdot 16 \\
(9 \text { to } 13)\end{array}$ & $\begin{array}{c}11.33 \\
(5 \text { to } 19)\end{array}$ & $\begin{array}{c}13.50 \\
(10 \text { to } 20)\end{array}$ \\
\hline
\end{tabular}

* Stage of pregnancy at operation. 
exposed by sham-operation and unexposed ovaries, or (b) between the ovaries of mice subjected to sham-operation at different times with respect to (i) the total volume of functional luteal tissue; (ii) the number of CL of pregnancy; (iii) the volume of CL of pregnancy. Differences between right and left ovaries just failed to reach significance with respect to (i) and (ii) above: the trend was in the direction expected from the observations of McLaren (1963a). There was no difference between the two sides with respect to (iii). Information from control animals was therefore pooled in tests carried out to see whether there was any evidence of compensatory changes in luteal tissue following hemiovariectomy. First, the mean volume of CL pregnancy in experimental animals was compared with that in controls; there was no evidence of change after operation (Table 3). Second, the total volume of luteal tissue in animals in

Table 3. The volume of corpora lutea of pregnancy at 18.5 days in hemiovariectomized animals and controls subjected to sham-operation

\begin{tabular}{l|c|c|c|c}
\hline & \multirow{3}{*}{ Controls } & \multicolumn{3}{|c}{ Hemiovariectomized animals } \\
\cline { 2 - 5 } & & 8.5 days* & 11.5 days & 14.5 days \\
\hline Mean & 38.09 & 37.47 & 35.53 & 37.54 \\
S.D. & 6.10 & 4.00 & 9.17 & 4.24 \\
\hline
\end{tabular}

Volumes expressed in terms of $\mathrm{mm}^{3} \times 10^{-2}$. For numbers of animals per group see Table 2.

* Stage of pregnancy at operation.

which only the right ovary remained in situ was compared with the amount in the right ovaries of controls (both ovaries present); a similar procedure was carried out for left ovaries. Right and left sides were treated independently in view of a possible difference between the two sides with respect to total luteal volume. The results gave no indication of difference between single ovaries in hemiovariectomized animals and controls. By contrast, a comparison of the total luteal volume present per mouse showed that differences between experimental animals (one ovary) and controls (two ovaries) were highly significant $(P<0.001)$. Thus, our results demonstrate that there was neither morphological hypertrophy amongst CL of pregnancy, nor 'recruitment' of accessory luteal tissue (e.g. by luteinization of atretic follicles to form 'nodules') in the ovary which remained after hemiovariectomy. Analyses also showed that there was no direct relationship between the total volume of luteal tissue found at autopsy and (a) the number of fetuses, (b) fetal weight, and (c) total placental weight.

It appears that development usually proceeds normally after hemiovariectomy during the postimplantation stages of pregnancy. Two observations are indicative of some alteration in the hormonal environment: (i) the total failure of pregnancy in two mice hemiovariectomized at 11.5 days, a stage of development known to be particularly sensitive to environmental change, coincident with the initiation of gonadotrophin secretion by the placenta (Cerruti \& Lyons, 1960); and (ii) early parturition in four mice which may have been the 
consequence of a premature reduction in progesterone and/or increase in oestrogen secretion by the ovary (Bedford, Challis, Harrison \& Heap, 1972). There was a compensatory increase in the number of Graafian follicles in the ovary which remained in situ after hemiovariectomy, the pattern of response being similar to that seen in the non-pregnant mouse (McLaren, 1963b). By contrast, there was no evidence of morphological compensation in luteal tissue (see also Brinkley \& Young, 1969). Thus, there is no evidence of a direct relationship between the quantity of luteal tissue and the number of conceptuses brought to term, although the survival of a litter would seem to be dependent upon the presence of a minimal and as yet undefined amount of functional luteal tissue and hence, perhaps, on a threshold level of progesterone.

We wish to thank Dr D. Darlington for advice and assistance with the statistical analyses. We are also grateful to Professor J. T. Eayrs, Dr E. C. Jones and Dr L. L. Franchi for helpful discussion. This work was supported by a grant made to Dr H. M. Beaumont by the U.S. Atomic Energy Commission (No. AT (11-1) 3114).

\section{REFERENGES}

Bedford, C. A., Ghallis, J. R. G., Harrison, F. A. \& Heap, R. B. (1972) The rôle of oestrogens and progesterone in the onset of parturition in various species. F. Reprod. Fert., Suppl. 16, 1.

BrinkLEY, H. J. \& Young, E. P. (1969) Effects of unilateral ovariectomy or the unilateral destruction of ovarian components on the follicles and corpora lutea of the non-pregnant pig. Endocrinology, 84, 1250.

BRUCE, H. M., Renwick, A. G. G. \& FinN, G. A. (1968) Effect of post-coital unilateral ovariectomy on implantation in mice. Nature, Lond. 219, 733.

Gerruti, R. A. \& Lyons, W. R. (1960) Mammogenic activities of the mid-gestational mouse placenta. Endocrinology, 67, 884 .

HarRis, R. G. (1927) Effect of bilateral ovariectomy upon the duration of pregnancy. Anat. Rec. 37, 83.

Mclaren, A. (1963a) The distribution of eggs and embryos between sides in the mouse. F. Endocr. $27,157$.

McLaren, A. (1963b) Mechanism of ovarian compensation following unilateral ovariectomy in mice. 7. Reprod. Fert. 6, 321.

Pritchard, J. J. \& Huggett, A. St G. (1947) Experimental foetal death in the rat: histological changes in the membranes. F. Anat. 81, 212.

Ross, M. H. (1973) Hormonal factors and reduced fertility in mice. B.Sc. thesis, Anatomical Studies, University of Birmingham.

Theiler, K. (1972) The House Mouse. Springer, Berlin.

Wu, J. T. \& Dickmans, Z. (1971) Unilateral ovariectomy during early pregnancy in rat: no effect on embryonic survival. Endocrinology, 88, 257. 